\title{
Health Problems of Professional Ballet Dancers
}

\author{
Tengiz Verulava ${ }^{1,2,3}$, Ketevan Tvalavadze ${ }^{4}$, Revaz Jorbenadze $^{5}$ \\ ${ }^{1}$ School of Medicine and Healthcare Management, Caucasus University, Tbilisi, Georgia \\ ${ }^{2}$ Faculty of Social and Political Sciences, Ivane Javakhishvili Tbilisi State University, Tbilisi, Georgia \\ ${ }^{3}$ School of Psychology and Public Health, La Trobe University, Melbourne, Australia \\ ${ }^{4}$ School of Humanities and Social Sciences, Caucasus University, Tbilisi, Georgia \\ ${ }^{5}$ Chapidze Emergency Cardiology Center, Tbilisi, Georgia
}

\begin{abstract}
SUMMARY
Ballet is a professional activity that places risky physical and psycho-emotional demands on the human body. The goal of this study was to evaluate health-related problems among ballet dancers. Within the qualitative study, in-depth interviews were conducted with ballet dancers at the State Ballet of Georgia. Participants' mean age was $23.4 \pm 3.5$ years, the average BMI - 21.2 \pm 2.2 . Dancers had spent $9.2 \pm$ 7.4 years studying dancing professionally. On average, they spent $8.5 \pm 5.8$ hours in class and $16.2 \pm 11.6$ hours in rehearsal. Most injuries were related to ankle/feet $(16 \%)$, knee $(60 \%)$, and neck $(13 \%)$. Common risk factors for incurring pain and injury included overuse (19\%), previous injury $(\mathbf{1 1} \%)$, and fatigue $(\mathbf{1 1} \%)$. Of the injured dancers, $\mathbf{8 0} \%$ chose to seek medical attention. Mostly, they visited traumatologists $(\mathbf{4 0} \%)$ and physiotherapists $(30 \%)$. The biopsychosocial condition of ballet artists is affected by physical workload, high risk of injuries, as well as constant stress. The result suggests high prevalence and recurrence of dance injuries. Ankle/feet, knee and neck are especially risky topological areas for injuries as particularly big pressure is placed on the feet and ankle joints. The majority of respondents seeked advice from medical specialists rather than family physicians. It is necessary to prevent injuries and stress through raising awareness. A team of professionals (family physician, orthopedist, psychologist, nutritionist, endocrinologist, physical therapist, nurse) is needed to prevent injuries. Family doctors should pay more attention to the promotion of a healthy lifestyle during the consultation with ballet dancers.
\end{abstract}

Key words: ballet dancers, health of dancers, health risks, stress, injuries

Corresponding author:

Tengiz Verulava

e-mail: tengiz.verulava@gmail.com 


\section{INTRODUCTION}

Ballet is a professional activity that requires physical and psycho-emotional strength from the dancer. Health risks of professional ballet dancers include physical pain, multiple types of injuries, eating disorders, and psychological problems $(1-3)$. Research shows that dancers have 1.38 injuries per 1000 hours of dancing (4). The most frequent are feet and ankle injuries, osteochondrosis of neck and waist vertebras, as well as orthopedical diseases (5), knee, feet, and hip arthrosis (6). The risks of injuries is increased with ballet jumps and turns, which, on the other hand, endangers the spinal column (7 - 8). Various research proves that a high level of a neurasthenic syndrome, which usually progresses with hypertensive type of vasomotor dyscrasia, is due to work characteristics (usually, performance process) (9).

According to the research, training duration, which is longer than 8.5 hours per week, increases the chances of back injuries by $38 \%$ (10). Injuries that have not been paid relevant medical attention are especially dangerous and severe (11). Fifty percent of respondents who had health problems due to their rehearsal and training did not address to relevant medical help. Moreover, it is very common to hide health problems, especially when women are concerned as they do not want to lose their dance partner, considering that finding a proper male ballet artist is always difficult. In such cases, $54 \%$ of respondents do not stop the training, avoid consulting doctors and accordingly, jeopardize their health.

Ballet dancers have a high risk of work-related stress and require a long training period. A ballet dancer's goal is to achieve technical and physical perfection, which is associated with a strong psychological load (12). Ballet dancers have a high risk of eating disorders due to diet control and often experience anorexia and bulimia (13). Malnourished ballet dancers are at a higher risk of injuries, scoliosis due to decreased bone density and long-term health problems (14).

The goal of this study was to evaluate healthrelated problems among ballet dancers.

\section{PARTICIPANTS AND METHODS}

Within the qualitative study, in-depth interviews were conducted among ballet dancers. The target group was artists of the State Ballet of Georgia (on average, at least 5 years of dance experience). Ten dancers volunteered to be interviewed (8 Georgian dancers, 2 foreign dancers). Of the total participants, 8 were female $(80 \%)$ and only two were male $(20 \%)$, which is in line with the trend that women are more represented in the ballet field.

Respondents were informed of the purpose of the study. Ethical approval was granted by the Ethics Committee at the Health Policy Institute (2019_08_09_HPI). We informed participants that participation in the study could retract their responses at any time during and after participation. Participants received unique identification codes and we informed participants that no one outside the research team had access to any study data.

Interviews were conducted in Georgian and English language (with foreign members of the company). The research was made in Tbilisi, Georgia.

The interviews conducted were semi-structured. Participants initially completed a brief paperbased questionnaire to gather basic demographic information and details about the age, sex, length of their dance careers, weekly dance load.

Audio recording of the interviews was gathered. Primary data was used, whereby we collected data ourself, using the interviews. The units of data analyses were words and phrases, where we recorded the interview and created a transcript afterwards.

\section{RESULTS}

Participants were aged between 20 and 27 years (mean: $23.4 \pm 3.5$ ). The average body mass index (BMI) was $21.2 \pm 2.2$. All of the dancers had trained extensively; they start ballet at an early age, usually when at 6-10 years old, moving on to a professional level at 14 . They took their first dance class at the age of $10.1 \pm 4.6$ years. Dancers had spent $20.2 \pm 7.4$ years studying dancing professionally (Table 1). Dancers were asked to report on the number of hours they spent in class and rehearsal each week. On average, they spent $8.5 \pm 5.8$ hours in class and $16.2 \pm 11.6$ hours in rehearsal. However, as all of them mentioned, it depends on the repertoire and upcoming performances.

Besides demographic data, the questionnaire enabled us to gather information about the following categories: health, addressing doctor/having insurance, stress, plans for the future. 
Table 1. Demographic characteristics (age, sex), years dancing, hours of dancing, means and standard deviations

\begin{tabular}{l|c|c}
\hline \hline $\begin{array}{l}\text { Participants } \\
\text { Female }(\mathrm{N}=8), \text { Male }(\mathrm{N}=2)\end{array}$ & Mean & SD \\
\hline Age $(\mathrm{y})$ & 23.4 & \pm 3.5 \\
\hline Height $(\mathrm{cm})$ & 165.3 & \pm 4.7 \\
\hline Weight $(\mathrm{kg})$ & 62.2 & \pm 8.6 \\
\hline Body mass index $\left(\mathrm{kg} / \mathrm{m}^{2}\right)$ & 21.2 & \pm 2.2 \\
\hline Age at first dance class & 10.1 & \pm 4.6 \\
\hline Studying dancing (years) & 20.2 & \pm 7.4 \\
\hline Professionally dancing (years) & 9.2 & \pm 6.5 \\
\hline Hours of dancing/week & 28.1 & \pm 4.1 \\
\hline $\begin{array}{l}\text { Time in dance class per } \\
\text { week (number of hours) }\end{array}$ & 8.5 & \pm 5.8 \\
\hline $\begin{array}{l}\text { Time in rehearsals per } \\
\text { week (number of hours) }\end{array}$ & 16.2 & \pm 11.6 \\
\hline \hline
\end{tabular}

\section{Competition and perfection}

The dancers often mentioned the competitive environment that characterizes the ballet world. They are competing for the best roles. Competition is high, which also causes psychological stress.

Respondent 1: "Everyone wants the leading part, this part in a certain ballet is only one and we cannot have two Romeos in one performance".

Respondent 2: "Every dancer has competition in their studio and throughout the world. They are all competing for the few jobs and to be the best at the type of dance that they are interested in".

Respondent 3: "Dance as a performing art form is still growing, positions are still very limited. The Theater wants the best of the best and the dancers know that. The dancers must fight by being the best in order to get the part that they want".

Respondent 5: "It will always be competitive trying to get to the next stage: trying to become a soloist, trying to become a principal".

Dancers have to spend a lot of time working out and perfecting their technique in order to compete with the other dancers. As a result, ballet is largely connected to perfectionism, in which perfection can never be achieved.

Respondent 7: "Our profession does not have an ultimate goal. We always try to get better, we practice more and more, but this is never enough".

Respondent 9: "You can never have perfect per- formance in ballet".

\section{Weight management}

Weight management has both physical and emotional consequences for dancers. The stress which is caused by visual image is linked by the respondents to extreme diets of the dancers as they constantly try to be as thin as possible.

Respondent 7: "Some dancers believe that if they are thinner, coaches will like them more and they will have a better chance of getting a role. This often leads to anorexia and ends with psychological problems".

Respondent 3: "Usually, I'm happy with my body, but in the dance sphere I'm not satisfied because it would be a lot easier to get a job if I had thin legs".

\section{Pain and injury}

While discussing health conditions, all of them admitted that their profession causes several physical and psychological problems. On completion of the 2year follow-up period, respondents were asked to report on up to three most bothersome episodes of pain/injury they suffered during this period. In total, 48 episodes of Pain and Injury episodes in all body regions were recorded over the 2-year period. According to the research, most injuries were related to ankle/feet $(16 \%)$, knee $(60 \%)$ and neck $(13 \%)$. As one of the respondents mentioned, because of special jumps and turns, their knee gets injured the most. Also, in case of male artists, pressure mostly comes on the left leg and the left knee. Because of trauma, one of the participants had to stop dancing for a while, which, on the other hand, led to psychological problems. Tendon, hip, and joint problems were mentioned, as well as knee and ankle deformations. In case of one of the leading soloists, during his ballet career, he had 20 minor traumas and 4 very serious ones. It is worth mentioning that all 10 participants had constant pain of at least one part of their body (Table 2).

Respondents identified a number of intrinsic and extrinsic factors perceived to be risk factors for incurring pain and injury. The most commonly cited reasons included overuse (19\%), previous injury $(11 \%)$, and fatigue (11\%) (Table 3). 
Table 2. Pain/Injury locations sustained in the previous two years

\begin{tabular}{l|l}
\hline \hline \multicolumn{2}{l}{ Pain/Injury locations $(\mathrm{n}=48)$} \\
\hline Neck & $6(13 \%)$ \\
\hline Shoulders & $1(2 \%)$ \\
\hline Elbow & $1(2 \%)$ \\
\hline Wrists/hands & $1(2 \%)$ \\
\hline Upper back & $5(10 \%)$ \\
\hline Lower back & $5(10 \%)$ \\
\hline Hips & $2(4 \%)$ \\
\hline Thighs (front) & $2(4 \%)$ \\
\hline Thighs (back) & $2(4 \%)$ \\
\hline Knees & $6(13 \%)$ \\
\hline Shins & $4(8 \%)$ \\
\hline Calves & $2(4 \%)$ \\
\hline Ankles/feet & $7(16 \%)$ \\
\hline Toes & $4(8 \%)$ \\
\hline Total & $48(100)$ \\
\hline \hline
\end{tabular}

Table 3. Perceived risk factors for pain/injury

\begin{tabular}{l|l}
\hline \multicolumn{2}{c}{ Perceived risk factors $(\mathrm{n}=36)$} \\
\hline Overuse & $7(19 \%)$ \\
\hline Previous injury & $4(11 \%)$ \\
\hline Accident & $2(6 \%)$ \\
\hline Poor warm-up/stretch & $3(8 \%)$ \\
\hline Footwear & $2(6 \%)$ \\
\hline Fatigue & $4(11 \%)$ \\
\hline Poor technique & $2(6 \%)$ \\
\hline Generalised weakness & $4(11 \%)$ \\
\hline Other (stress, flooring, fitness) & $4(11 \%)$ \\
\hline Unknown/unspecified & $2(6 \%)$ \\
\hline Total & $36(100 \%)$ \\
\hline \hline
\end{tabular}

\section{Stress}

In addition, this profession is filled with psychological problems and stress.

Respondent 10: "No one works without psychological stress, but in our case, this is a combination of constant physical and psychological stress".

Such a high level of stress is also based on image, on the way you look on stage and how audience perceives you.

Respondent 8: "You need to look special to have an effect on audience; also, you need to deserve liking from ballet masters and coaches to get a role".
Respondent 4: "It is very time-consuming and strenuous. Rehearsals require very long hours and usually take place daily, including weekends and holidays".

Respondent 6: "Almost all the performances take place in the evening. Dancers get little sleep and become accustomed to working late and long hours."

Psychological stress is intensified by the fact that professional career in ballet has very restricted limits in age.

Respondent 2: "Ballet is young people's profession. Realizing that your career does not have longterm future causes depression".

Career limits are also connected to traumas.

Respondent 3: "One serious injury and your career can be over in one day; you will never be able to be on stage again. Not in our company, but I know many who are in this situation".

In addition to the abovementioned stressors, society has a stereotyped attitude to ballet. Both male dancers mentioned society's attitudes; it is a fact that people do not perceive ballet as a male's profession.

Respondent 8: "Very often people have told me that ballet is not for men, but I have never paid attention to it".

Respondent 9: "People do not think of ballet as a serious profession, mostly because they do not know it in-depth. It is very easy to watch performance and enjoy it".

Each of the participants have their own ways of dealing with stress, for one it is meditation, for other reading a good book, for some going for a walk or even an honest conversation with a friend. It is true that social integration helps people to deal with stress situations; however, some differences were revealed between Georgian and foreign dancers. As Georgians have relatives, friends and many acquaintances, integration problems are less common for them, while in case of foreign dancers, adaptation to the new environment and new culture are additional stressors until they adopt properly. One of the respondents mentioned that "Ballet artist does not have a social life".

Considering career duration limitations, each of the research participants have thought about future after completing ballet career. One of them is in the process of passing exams to get accepted at university, but still wishes to be connected with ballet.

Respondent 3: "I think I will become a ballet coach or consultant psychologist for dances, as I think it is very much needed for us". 


\section{Visit to a doctor}

All participants have insurance. As foreign dancers explained, having insurance in Georgia is part of their work contract. The majority $(30 \%)$ of the injuries resulted in absence from dance for 1 to 2 weeks and $20 \%$ required absence of 5 weeks or more. Of the injured dancers, $80 \%$ chose to seek and $20 \%$ did not try to seek medical attention. All dancers have a family doctor, but referral rate to a family physician was low $(30 \%)$. Based on ballet characteristics, they mostly visit traumatologists $(40 \%)$ and physiotherapists (30\%). Large majorities $(90 \%)$ were nonsmokers and $90 \%$ did not drink alcohol (Table 4).

Table 4: Required absence from dance, seek medical attention, consulting a doctor

\begin{tabular}{l|l}
\hline \hline Required absence from dance & \\
\begin{tabular}{l|} 
1 - 2 weeks \\
2 - 3 weeks
\end{tabular} & $3(30 \%)$ \\
3 - 4 weeks & $3(30 \%)$ \\
$>5$ weeks & $2(20 \%)$ \\
\hline Chose to seek medical attention & $8(80 \%)$ \\
Do not seek medical attention & $2(20 \%)$ \\
Consulted a family doctor & $3(30 \%)$ \\
Consulted a traumatologists & $4(40 \%)$ \\
Consulted a physiotherapists & $3(30 \%)$ \\
\hline Tobacco users & $1(10 \%)$ \\
\hline Yes & $9(90 \%)$ \\
No & $1(10 \%)$ \\
\hline Alcohol consumer & $9(90 \%)$ \\
\hline Yes & No \\
\hline \hline
\end{tabular}

Respondent 2: "I visit family doctor just because I need special paper which is needed to visit traumatologist"

Respondent 7: "To visit a doctor is one way of dealing with the problem; taking care of yourself is more important".

All participants recalled a situation when they refused to visit a doctor because of rehearsal or performance, and delayed a visit until pain was not bearable any more.

Respondent 4: “Now, I already know when I can tolerate pain myself and when I need to address a doctor".

Respondent 8: “I remember, once, we were pre- paring for the premiere of the Swan Lake, during the previous days I caught a cold and for four days straight I was rehearsing while having fever, and I performed on stage on the premiere days with having temperature of 40 degrees".

Respondent 5: "Because we get notified about the next day's schedule very late, it is even hard to make an appointment with the doctor so I have to endure the pain and delay visit to a doctor".

Respondent 2: "I have constant pain in some parts of my body and of course I cannot go to a doctor every day, I go when I feel it is serious".

\section{DISCUSSION}

The average BMI $(21.2 \pm 2.2)$ is relatively similar compared to other studies of ballet dancers (15). According to previous researches, ballet dancers' average height ranges from 160 to $170 \mathrm{~cm}$ and average weight from 53 to $70 \mathrm{~kg}$ (16), which is similar to the ballet dancers in the present study. In this study, we find that female ballet dancers begin studying at a much younger age than males. This may simply reflect the types of training classes available for students at different ages, as females begin studying at a much younger age than males (17).

The hours of weekly training have been reported in other studies (18). Overuse, previous injury and fatigue as a result of over-training have been identified as the most common risk factors for dance injuries. The result suggests the high prevalence and recurrence of dance injuries. Ankle/feet, knee and neck are especially risky topological areas for injuries as particularly big pressure is placed on feet and ankle joints, caused by long-term dance training. The high prevalence and recurrence of dance injuries as well as its tendency to affect the lower limbs have also been previously reported (19). This may be related to repetitive movements of the dance, which affects the foot and ankle regions (20 - 21).

The proportion of dancers that chose to seek medical attention was high. Most of the injured ballet dancers sought treatment from health professionals (traumatologists and physiotherapists), which is relatively similar compared to other studies (22). The results suggest that the patient's low referral rate to a family physician was due to distrust towards family physicians. Studies confirm that in Georgia many patients seek care without a referral of a family physicians, which is related to the low public aware- 
ness of the family physician's competence (23 - 25). The prevalence of smokers and non-drinkers in the study is considerably lower than that of the national average (26 - 28).

The biopsychosocial condition of ballet artists is affected by physical workload, high risk of injuries, as well as constant stress. Illnesses and biopsychosocial factors related to ballet profession deserve proper attention.

\section{CONCLUSION}

The most recommended intervention is the prevention of injuries and stress through education targeting prevention of injuries, hazards of dieting, rehabilitation. A team of professionals is needed, which consists of a family physician, orthopedist, psychologist, nutritionist, endocrinologist, physical therapist, and occupational nurse. The family physician can provide continuing education related to nutrition, prevention of injuries and physical therapy. Family doctors should pay more attention to promoting a healthy lifestyle and to educate dancers about stress prevention and coping skills.

\section{References}

1. Smith PJ, Gerrie BJ, Varner KEl et al. Incidence and prevalence of musculoskeletal injury in ballet: a systematic review. Orthop J Sports Med 2015; 3(7): 1-9.

https://doi.org/10.1177/2325967115592621

2. Shah S. Caring for the dancer: special considerations for the performer and troupe. Curr Sports Med Rep 2008; 7: 128-32.

https://doi.org/10.1097/01.CSMR.0000319716.56169.29

3. McEwen K, Young K. Ballet and pain: reflections on a risk-dance culture. Qual Res Sport Exerc Health 2011; 3(2): 152-73.

https://doi.org/10.1080/2159676X.2011.572181

4. Ekegren CL, Quested R, Brodrick A. Injuries in preprofessional ballet dancers: Incidence, characteristics and consequences. J Sci Med Sport 2014; 17(3): 271-5.

https://doi.org/10.1016/j.jsams.2013.07.013

5. Sobrino FJ, Guillen P. Overuse Injuries in Professional Ballet: Influence of Age and Years of Professional Practice. Orthop J Sport Med 2017. https://doi.org/10.1177/2325967117712704

6. Cahalan R, Purtill H, O'Sullivan K. Biopsychosocial Factors Associated with Foot and Ankle Pain and Injury in Irish Dance. Med Probl Perform Art 2017; 32(2): 111.

https://doi.org/10.21091/mppa.2017.2018

7. Smith TO, Davies L, Medici A et al. Prevalence and profile of musculoskeletal injuries in ballet dancers: A systematic review and meta-analysis. Phys Ther Sport 2016; 19: 50-6.

https://doi.org/10.1016/j.ptsp.2015.12.007

8. Corsta MSS, Ferriera AA, Orsini $\mathrm{M}$ et al. Characteristics and prevalence of musculoskeletal injury in professional and non-professional ballet dancers. Braz J Phys Ther 2016; 20(2): 166-75. https://doi.org/10.1590/bjpt-rbf.2014.0142

9. Kvartskava M, Saakadze V, Tsimakuridze M et al. Health Peculiarities Among Georgian National Ballet Dancers. Georgian Med News 2006; (136): 121-4.

https://pubmed.ncbi.nlm.nih.gov/16905865/ 
10. Miletic D, Miletic A, Lujan IK, Kezic A. Health Care Related Problems Among Female Sport Dancers. J Hum Kinet 2015; 20(1): 57-62. https://doi.org/10.1123/ijatt.2014-0021

11. Golubović Z, Popović Z, Milenković S, et al. Missile injury of the knee joint. Acta Fac Med Naissensis 2013; 30(4): 225-31.

https://publisher.medfak.ni.ac.rs/AFMN 1/2013/42013/7.pdf

12. Hamilton LH, Hamilton WG. Occupational stress in classical ballet: The impact in different cultures. Med Probl Perform Ar 1994; 9(2): 35-8. https://www.sciandmed.com/mppa/journalviewer. aspx?issue $=1120 \&$ article $=1240$

13. Maloney MJ. Anorexia nervosa and bulimia in dancers. Accurate diagnosis and treatment planning. Clin Sports Med 1983; 2(3): 549-55. https://doi.org/10.1123/ijatt.2014-0021

14. Bettle N, Bettle $\mathrm{O}$, Neumärker U, Neumärker KJ. Adolescent ballet school students: their quest for body weight change. Psychopathology 1998; 31(3): 153-9.

https://doi.org/10.1159/000066238

15. Ferrari EP, Silva DA, Martins CR et al. Morphological characteristics of professional ballet dancers of the Bolshoi theater company. Coll Antropol 2013; 37: 37-43.

https://hrcak.srce.hr/102455

16. WHO. Physical status: the use and interpretation of anthropometry. Report of a WHO Expert Committee. WHO Technical Report Series 854. Geneva: World Health Organization. 1995. https://scholar.google.com/scholar?hl=en\&as sdt=0 $\% 2 \mathrm{C} 5 \& \mathrm{q}=$ Physical+status $\% 3 \mathrm{~A}+$ the+use+and+interp retation+of+anthropometry.+Report + of $+\mathrm{a}+\mathrm{WHO}+\mathrm{E}$ xpert+Committee\&btnG=

17. Evans RW, Evans RI, Carvajal S. Survey of injuries among West End performers. Occup Environ Med 1998; 55: 585-93.

http://dx.doi.org/10.1136/oem.55.9.585

18. Bowling A. Injuries to dancers: prevalence, treatment, and perceptions of causes. Br Med J 1989; 298: 731-4. https://doi.org/10.1136/bmj.298.6675.731

19. Shah S, Weiss DS, Burchette RJ. Injuries in professional modern dancers: incidence, risk factors, and management. J Dance Med Sci 2012; $16,17-25$.

https://www.ingentaconnect.com/content/jmrp/jd $\mathrm{ms} / 2012 / 00000016 / 00000001 / \operatorname{art00003}$

20. Baker J, Scott D, Watkins K et al. Self-reported and reported injury patterns in contemporary dance students. Med Probl Perform Art 2010; 25(1): 10-5. https://www.sciandmed.com/mppa/journalviewer. aspx?issue $=1183 \&$ article $=1814$

21. Weiss DS, Shah S, Burchette RJ. A profile of the demographics and training characteristics of professional modern dancers. J Dance Med Sci 2008; 12: 41-6.

https://www.ingentaconnect.com/content/jmrp/jd $\underline{\mathrm{ms} / 2008 / 00000012 / 00000002 / a r t 00001}$

22. Pollard-Smith T, Thomson OP. Professional ballet dancers' experience of injury and osteopathic treatment in the UK: A qualitative study. J Bodyw Mov Ther 2017; 21(1): 148-56.

https://pubmed.ncbi.nlm.nih.gov/28167171/

23. Verulava T, Jorbenadze R, Karimi L. Patients' perceptions about access to health care and referrals to family physicians in Georgia. Arch Balk Med Union 2020; 55(4): 642-50. https://doi.org/10.31688/ABMU.2020.55.4.11

24. Verulava T, Dangadze B, Jorbenadze R, Lordkipanidze A, Karimi L, Eliava R, Maglakelidze T. The Gatekeeper Model: patient's view on the role of the family physician. Fam Med Primary Care Rev 2020; 22(1): 75-79.

https://doi.org/10.5114/fmpcr.2020.92511

25. Verulava T, Beruashvili D, Jorbenadze R, Eliava E. Evaluation of patient referrals to family physicians in Georgia. Fam Med Primary Care Rev 2019; 21(2):180-3.

https://doi.org/10.5114/fmpcr.2019.84555

26. Berg CJ, Aslanikashvili A, Djibuti MA. CrossSectional Study Examining Youth Smoking Rates and Correlates in Tbilisi, Georgia. Biomed Res Int 2014: 476438 . 
https://doi.org/10.1155/2014/476438

27. Verulava T, Nemsadze D, Jorbenadze R, Dangadze B. Factors that influence tobacco use in Georgian youth. Malta Med J 2020; 32 (2): 49-58 https://www.mmsjournals.org/index.php/mmj/arti cle/view/275/937

28. Mukeria M, Kiknadze B, Verulava T. The Impact of the Tobacco Control Law on Youth Tobacco Use. Arch Balk Med Union 2020; 55 (1):108-12. https://doi.org/10.31688/ABMU.2020.55.1.12

\title{
Zdravstveni problemi profesionalnih baletskih igrača
}

\author{
Tengiz Verulava1, 2,3, Ketevan Tvalavadze ${ }^{4}$, Revaz Jorbenadze ${ }^{5}$ \\ ${ }^{1}$ Fakultet za medicinu i zdravstveni menadžment, Kavkaski univerzitet, Tbilisi, Gruzija \\ ${ }^{2}$ Fakultet za društvene i političke nauke, Državni univerzitet Ivane Javakhishvili Tbilisi, Tbilisi, Gruzija \\ ${ }^{3}$ Fakultet za psihologiju i javno zdravlje, Univerzitet La Trobe, Melburn, Australia \\ ${ }^{4}$ Fakultet za humanističke i društvene nauke, Kavkaski univerzitet, Tbilisi, Gruzija \\ ${ }^{5}$ Centar za urgentnu kardiologiju Chapidze, Tbilisi, Gruzija
}

\section{SAŽETAK}

Balet je profesionalna aktivnost koja ljudskom telu postavlja rizične fizičke i psihoemocionalne zahteve. Cilj ove studije bila je procena zdravstvenih problema baletskih igrača. U okviru kvalitativne studije, urađeni su dubinski intervjui sa baletskim igračima Državnog baleta Gruzije. Srednja starost učesnika iznosila je 23,4 godine $\pm 3,5$ godina, a prosečna vrednost indeksa telesne mase $21,2 \pm 2,2$. Igrači su se profesionalno bavili baletom 20,2 godine $\pm 7,4$ godine. $\mathrm{U}$ proseku su provodili 8,5 sati $\pm 5,8$ sati na časovima $i$ 16,2 sata $\pm 11,6$ sati na probama. Većina povreda odnosila se na skočni zglob / stopalo $(16 \%)$, koleno $(60 \%)$ i vrat (13\%). Najrizičniji faktori za nanošenje povreda uključivali su prekomerno opterećenje $(19 \%)$, prethodne povrede $(\mathbf{1 1} \%)$ i umor $\mathbf{( 1 1 \% )}$. Osamdeset posto povređenih igrača odlučilo je da potraži medicinsku pomoć. Uglavnom su posećivali traumatologe $(\mathbf{4 0} \%)$ i fizioterapeute $(\mathbf{3 0} \%)$. Biopsihosocijalno stanje baletskih igrača uslovljeno je fizičkim opterećenjem, visokim rizikom od povreda, kao i konstantnim stresom. Rezulati ukazuju na visoku prevalenciju i ponovno javljanje povreda. Skočni zglob / stopalo, koleno i vrat naročito su rizična područja za nastanak povreda, jer je najveći pritisak na stopalima i skočnim zglobovima. Većina ispitanika radije traži medicinsku pomoć od specijalista medicine, nego od porodičnog lekara. Da bi se sprečile povrede $\mathrm{i}$ stres, neophodno je raditi na podizanju svesti. Neophodan je tim profesionalaca (porodični lekar, ortoped, psiholog, nutricionista, endokrinolog, fizikalni terapeut i medicinska sestra) kako bi se sprečio nastanak povreda. Porodični lekari bi trebalo da obrate više pažnje na promovisanje zdravog života u toku konsultacija sa baletskim igračima.

Ključne reči: baletski igrači, zdravlje igrača, zdravstveni rizici, stres, povrede 